\title{
Public Interest in Criminal Procedure and Its Challenges: An Attitude toward Iranian Criminal Law
}

\author{
Seyyed Jafar Es-haghi ${ }^{1} \&$ Mahdi Sheidaeian ${ }^{2}$ \\ ${ }^{1}$ Department of Criminal Law and Criminology, Qom Branch, Islamic Azad University, Qom, Iran \\ ${ }^{2}$ Faculty of Law, Farabi College, University of Tehran, Qom, Iran \\ Correspondence: Mahdi Sheidaeian, Faculty of Law, Farabi College, University of Tehran, Qom, Iran. E-mail: \\ m_sheidaeian@ut.ac.ir
}

\author{
Received: January 11, 2016 Accepted: June 15, 2016 Online Published: June 29, 2016 \\ doi:10.5539/jpl.v9n5p1 URL: http://dx.doi.org/10.5539/jpl.v9n5p1
}

\begin{abstract}
Greek philosophers had accepted "rule of law" as desired governance system since it was the only way to provide all citizens' public interest. In today's societies where public policy is accountable for the interests of total society or at least its majority, it is too vital to recognize the concept of public interest. Like other concepts, it is also radically transformed in modern age, despite varied perceptions on this concept, modern concept of public interest is understood as recognizing individual rights, accepting utility principle which means to attract the highest interest for most people, respecting legal process and adapting with common values of society independent of individual interests.

Criminal procedure is shaped in three main areas including criminal process, entities and its governing laws affected by public interest concept. Regulations such as competencies and penal provisional remedy, entities like the public prosecutor's office and NGOs and criminal process models like crime control are all justified by this concept. In present paper, it is attempted to adapt such claim to Iranian procedural rights by some illuminations.

One can claim that criminal procedure is one of the most obvious arenas of public interest where individual rights and freedoms clash. Since criminal procedure is set to provide public interest like many other laws, it also supports individual rights. Such rights include both procedural and substantial rights. On this basis, criminal procedure aims at achieving a balance point between public interest and individual interest. Here, we study the challenge of four rights supported by criminal procedure on public interest in Iranian laws.
\end{abstract}

Keywords: public interest, criminal procedure, individual rights

\section{Introduction}

"Public interest" or "common good" is similar to the "law" concept. Many philosophers believe that providing public interest is a favored trait of law. All Greek philosophers had accepted "rule of law" as desired governance system since it was the only way to provide all citizens' public interest (Mirmosavi, 2005: 70). On this basis, it is claimed that the concept of public interest some of its equivalences are as old as political philosophy. For instance Aristotle pointed out "common interest", Aquinas mentioned "common good", Jon Lock introduced "public good of people", David Hume pointed out "public good", Madison explained "public, common or general good" and Russo provided "common good" (Diggs 1973: 285).

In all these cases, public interest or common good is seen equal to morality, justice and the best ends of government or political society. Even, some authors like John Stuart Mill who allocated it decisively to individual liberty accepted to confirm common welfare or general or societal interest. Therefore, public interest or common interest exists everywhere and has generated a broad range of equivalences which express that there is a common good that involves total society and is distinguished from individual, sectional or regional interests described as common vision, shared vision, shared purpose, common goals, social contract, core value and general welfare. Briefly, public interest concept is inevitable and necessary for a modern democracy in which it is assumed that public policy is accountable for the interests of total society (or at least, a remarkable maximum part of it) rather than a section (Pal \& Maxwell, 2004: 3) and, hence, it should be defined.

Some authors have made effort to define "public interest" similar to defining "love". It is obvious that love means different things for different persons under different circumstances. It can be changed over time both 
procedurally and substation. Like love, public interest means different things for different persons who change over time, stimulate behavior, give framework to our opinions, does not accept calibration, and involve nature and process (Denhardt \& Denhardt, 2010: 6). On this basis, all components of governance and public entities should look for purveying public interest. Public services are shaping based on public interest.

Executing justice, discipline and security is a service to society through crime prosecution, trail and executing the verdicts by criminal justice system. Like other public services, it looks for providing public interest. Criminal procedure is a way to execute criminal justice through public interest. According to classic perception, resolving conflicts between public interest and individual interest is the main aim of criminal procedure. According to this insight, supporting public interest requires rapid and critical punishment of all crimes. Technically, a pattern of criminal procedure system adapted to this system is "inquisitorial adjudication system". In contrary, individual interest needs to conduct an impartial and profound investigation on the possibility of criminality so that one can assure non-prosecution, investigation and conviction for a crime which is not committed. Achieving such important result is technically possible in accusatory adjudication system.

To conduct such conflict, classic authors believed that criminal procedure should attempt to find a fair balance between individual and public interests. However, achieving such balance is too difficult so that some authors have considered as a perfect ideal that we should look for it without hoping to achieve it. Contemporary authors believe that achieving such compromise is the radical problems of criminal procedure (Gessen, 2006: 337 - 338) It seems that mixed or French adjudication system is an effort to achieve such balance point between public interest and individual interest so that the principles of inquisitorial adjudication are gathered in preliminary investigation steps and accusatory adjudication principles in trial step. Such balance point was modified over time that most important one was tendency to accusatory adjudication and respecting individual rights of the accused in preliminary investigating step. It seems that such transformations occurred due to public interest concept transformation since nowadays, respecting individual rights and freedoms are seen as an important implication for public interest and this concept pays attention to an individual and his/her rights.

In present paper, we attempt to answer these questions: what does public interest mean? What is its status in procedural penal laws? What is its main challenge? Authors assume that although public interest is a concept independent from individual interest, it is not separate from it. Public interest is the window of public services including judgments emerged in three areas: criminal process, regulations and criminal procedure entities. Likewise, the most important challenge for public interest includes individual rights. Therefore, upon brief recognition of public interest, we study its position in criminal procedure and its major challenge.

\section{Public Interest Concept}

Before entering the discussion on public interest concept, it is necessary to mention some points; first, one should go beyond legal borders to look for public interest concept since in terms of a theory on laws and other knowledge namely "epistemological foundationalism," radical concepts like public interest are not defined by such method in laws; rather, one should go to politics science and political philosophy as well as collected definitions over time on public interest in laws in order to accept it as a "basic" and "unjustifiable" item, (Omrani and Habibzadeh, 2013: 59 - 60).

Second, like other human and social sciences, public interest concept is transformed in modern age due to transformations in glancing the society, politics and laws. The trend from "public good" which does not recognize individuality for "public interest" which can be aggregated with individuals and individual rights is the witness of such claim. On this basis, the process to achieve public interest is global not in contrary to individuals and their rights. Public interest can be shaped by recognizing the individual and his/her rights and the interests of individual and society are in the same line (Alamdari, 1999: 204). Public interest is normative while it belongs to the scope of right not scope of goodness (Rasekh and Bayat, 2013: 567). In other words, it is a political not ethical concept. It is limited to a certain territory and nation. It is relative and differs based on society - by society in historic, social and geographical conditions. The way to explore it is rational and depends on accepted basics of lawmaking in any society. The authority to recognize public interest is democratic structure and collective lawmaking as the representative of society and impartial in terms of values. It is objective and realistic rather than objective and idealistic. It is extracted from the needs and difficulties of society.

Three, four different propensities have addressed public interest: social psychology propensity, legal propensity, philosophical propensity and political propensity of interest clash. Their first group believes that public interest is equal with some psychological concepts. According to this group philanthropic interests differ from selfish ones and go beyond it which is the same public interest (Khalil, 2003: 16). Theoreticians of the second group believe that law reflects public interest. As a result, interest pressure occurs during competition. Also, they 
believe that law is created balance in existing interests. In fact, law imagines the deliverables of governmental process and lawmaking (ibid: 17). As the most popular figure in this propensity, Resco Pand believes that the main task of laws is "social engineering." Social engineering has two steps: in the first step, one should attend which interests exist in any society and what are their types and importance extents. In the second step, a measure is needed to calibrate the values and to show that which one should be seen as interest clash. In this step, "legal philosophy" plays a vital role and it should define the respected ideals in each society (Katuzian, 2009: 487). He divided interests into three groups: individual, public (governmental) and social. Social interests that are our public interests include demands, needs and claim on social life in a civilized society. These interests are also divided into six groups: public security, social security entities, public ethics protection, social resources retaining, public progress and individual life (ibid: $488-494$ ).

The third or philosophical propensity includes a lot of subgroups the most important ones include: finalist ethical studies, Christian, Liberal and Socialist, ethical finalists such as utilitarianisms who look for public interests in improving the benefits of most people. In the thoughts of Christian thinkers, public interest is described in line with saving humans and prosperity in the next world (Mirmosavi, ibid: 47). In liberal thinkers' attitude, public interest is not clarified precisely and decisively; rather, it is for-ever changing and is fluctuating from no interference to labor and resource public management to meet private interests (Khalil, ibid: 22). In contrary, socialistic attitude used fixed and abstract entities in studying public interest. According to Marx, human is labor more than anything else and if he/she acts based on private ownership, the abstract and exclusive trait of such ownership is to separate human from human which would yield into withdrawal and hate. What conducted through humanity is general since social system is based on collective work and management. Labor system changes to political system when labor conditions are based on common traits. Here, labor and its management is converted into public interest (ibid).

Theoreticians of the fourth group determine public interest concept under interest clash concept, they believe in paramount groups and their interests. For many of these theoreticians, it is hard to accept that public interest is a normative concept while they do not like to put aside this concept that public interest is a measure for public policy and they believe that it is an important element in decision making process. They are also called "process theoreticians" since they relate public interest to the process of compromising with rivals' interests (ibid: 23).

Finally, to provide a definition on public interest, one should remove relevant paradoxes on individuals and groups; the relationship between public and private interests and the relationship between idea and structure. For example, a modern public interest theory cannot neglect the individuality of people in society or cannot victimize private interests in the name of protecting collective ones. Also, it is not justified to neglect public interest for the priority of private interests (Alamdari, 1999: 197).

During history, various definitions are represented on public interest. Some definitions have addressed the profoundness of its nature while other have emphasized on how to recognize and achieve it. In the first group, some have emphasized on the nature of "interest" and have considered it as tendency, need and interest and, consequently, have described it as "public tendency", "public need" and "public interest". Another group has defined public interest as the result of gathering of people namely administration and has described public interest as "total interest of people" or "administration interest". In contrary, some believe that it is the result of "democratic process", "total private interests aggregation" and "individual interests integral." It seems that each definition covers a part of reality although they are not alone sufficed to the purpose. Those who believe that public interest is independent from private ones, those who look for it in order to maximize individual interests and those who believe that it is the result of democratic process all define a part of this light in darkness.

It seems that despite of all differences in definitions, there is an agreement on some points: first, in current age, a full definition of public interest cannot ignore individuality of all public members. To the same reason, it should pay attention to individual rights as well as public demands and opinions so that collective and societal definitions should take account the individual and his/her rights and interests in their calculations. Therefore, an accepted aspect of public interest definition is to consider the status of an individual and his/her rights and interests which should be respected in any comprehensive definition on public interest. Second, utilitarianism which means attracting the highest utility for society's members should be another column of public interest definition. Third, it is necessary to pass certain legal protocols and processes to form public interest in a society. Fourth, although public utility pays attention to both private and individual interests, it is independent from them paying attention to difference between "the will of all individuals" and "public will" by Russo or difference between "similar interests" and "common interests" by Mac Ivor in social psychological studies or difference between public interest and private interests by Hobbs who distinguishes human from animals, all indicate the independence of public interests and private interests of society's members. Common interests or what 
interpreted as "public goods" such as clean air, sanitary water, security, public safety and efficient economy are things created for one person or the usage by one person prevents using by others. Fifth is to respect radical and accepted values in society; one cannot consider something in the interest of society while clarifying it in clash and conflict to public values. Likewise, public interest impacts on public policy decision makings as radical normative by which citizens agree/disagree with decisions by public officials.

According to above points, one can achieve a relatively comprehensive understating on public interest by combining five factors of respecting legal protocols and processes, attracting the opinions of majority, attracting highest value for most people, adaptability to common interests and society's common values (Pal and Maxwell, 2004: 7).

In general laws, some implications are mentioned for public interest including public order, public security, minimum level of public health and well - being, public training and public welfare. Their traits include being excellent, minimum, collective and ethical impartial without them, there will doubts on human collective survival; hence, one can call them as decisive or minimum implications of public interest (Rasekh and Bayat, 2013: 567). According to some insights, one can add to them public ethics (Hart, 2009: 20). As a branch of public law, criminal law has supported these implications. However, the extent of respect is not identical in criminal laws. For instance, some legal systems do not oblige themselves to support public ethics; on the other hand, some implications like public discipline and security have their special status in criminal laws.

In Iranian criminal law, "public reputation" of all crimes is either due to "breaching Divinity laws and regulations" or due to "violating societal laws and interference in public order" (article 8(a) of Iranian Procedure Law). If not saying that in all crimes such as discretionary ones not competent for Divinity punishments especially on "non-quotation ones", general aspect of crime is established due to violating societal rights and public order. On this basis, a public claim is shaped which aims at keeping Divinity laws and regulation or societal rights and public order (article 9(a) of Iranian Procedure Law). Therefore, a public claim is prosecuted in discretionary crimes for keeping societal rights and public order.

\section{Public Interest Implications}

One can study criminal procedure in three main fields: criminal process, entities and governing regulations. Criminal procedure includes steps from detention to punishment execution. Criminal procedure actors and entities play their role in this process and this process and its actors are limited to a hierarchy of regulations. Below, we study implications of public interest in three sectors: regulations, entities and criminal justice process.

\subsection{Regulations}

As mentioned, any law including criminal procedure law should purvey public interest. Overall, adaptability to public interest is the measure of fairness of each law. In criminal procedure law, public interest has a special status. For instance, one can point out regulations on criminal remedies/competencies and judicial supervision.

Competencies are a major discussion in substantial criminal laws. Court competency means the competency of an authority to investigate on a case. In criminal affairs, such authority should have the competency and autonomy to intervene and investigate the case (Khaleghi, ibid: 275). Basically, laws and regulations on competencies are seen as imperative laws on public order that all judicial authorities including prosecuting and verdict issuing authorities are obliged to respect it and its infraction is not allowed (ibid: 274). Designating and assigning competencies to judicial authorities are conducted by public interest and order and inner competency of public and private authorities are defined as the same basis. In Iranian criminal laws (article 301), criminal court introduces two public authorities while lawmaker has specialized courts line criminal court 1, revolutionary court, military court, juvenile court and special disciplinary tribunal for the clergy.

It seems that two types of interests cause the prediction of private authorities: the importance of accusation and the heaviness of punishment; and the accused's personality and social status. The competency of private authorities like criminal court 1 and revolutionary court is to determine the special importance of accusation while the competency of other private authorities such as military courts, juvenile court and clergy court are determined by the accused's' personality and asocial situation. basically, the aim of establishing private authorities and differential proceeding is changes in the approach of criminal process and verdict execution toward such crimes as offences against public security and showing the soft or hard face of criminal process and verdict execution to certain persons so that the first face is toward children and the second one is toward militarists. Differential proceeding on militarists is due to the fact that society looks at them when protecting national security and cohesion. Hence, their law violations are more highlighted than civil citizens (Alipour, 2010: 31 -32). General rule in local competency to try the accusation is applicable in a court in the jurisdiction 
the crime is committed (article 310, criminal procedure law) by which better accessibility to evidences is based on this rule. In local competency, several competencies are mentioned such as the accused's personality and social status, time and cost saving and public discipline and security as the main reasons for withdrawing the ruling general norms. There are three exceptions for local competency principle: additional competency, turning over and the competency of Capital and Province Capital Competencies. All three groups are adopted based on competencies which facilitate justice execution. The reasons such as better regulation respect on crime paramount, saving the time and costs of judiciary and preventing the issuance of contradictory verdicts are raised to justify additional competency to court (Khaleghi, pp. 283 - 284). Likewise, in article 420 of criminal procedure law, "public security and discipline protection" is mentioned as a legitimate reason for turning over. The third issue is the exclusive competency of Capital or Province Capital courts. In some cases, due to the importance of crime and the necessity of more careful trial in central courts or due to official position of perpetrator whose service location is in the Capital or Province Capital, the lawmaker has derogated from general principle of local court competency and has announced exclusive trial by Tehran or Province Capital courts (Khaleghi, 2010: 295). Therefore, the competency system including both principles and exceptions defined by procedural laws are based on public interests.

Criminal provisional remedies are applied to provide public interest (the rights of both society and victim) in relevant laws and judicial authorities. As clarified in article 217 of criminal procedure law, "to access the accused and his/her on-time attendance, preventing his escape or hidden and ensuring the rights of victim to compensate his/her losses." The most radical application of criminal justice system is to curb criminal phenomenon through prosecution, trial and punishment which is impossible without access to the accused and preventing his/her escape and hiding and lawmaker has considered it necessary to provide the possibility of performing the main task of criminal justice system. Likewise, compensating the losses of victim is not separated from public interest since without it, the feeling of security would not return to society and only prosecution, trial and punishment of offender would not assure citizens on the possibility of being victim.

Public interest is well reflected in the conditions of issuing temporary detention remedy in article 238 of criminal procedure law. Accordingly, issuing temporary detention remedy in article 237 of the same law depends on one of the mentioned conditions and all are an implication of disorder in criminal justice execution. These conditions include: (a) the accused's release would cause destroying all crime evidences or collusion with other accused people or witnesses and informants or would cause that witnesses refuse giving their testimonies. (b) The fear of the accused's escaping or hiding which cannot be prevented by other ways. (c) The accused's release would lead to disorder in public discipline, would jeopardize the life of plaintiff, witnesses, their families or the accused. As seen, under such conditions and in important crimes (mentioned in article 237), negating the liberty of under person is allowed since justice execution and proportionate reaction to a crime which has disordered public discipline is not impossible by any other way and in the case of detention, the accused may destroy crime evidences and make justice execution impossible through for instance collusion.

\subsection{Criminal Justice Entities}

By contemplating on actors and entities of criminal justice, one finds that it is institutionalized by public interest. As the main established entity on this basis, one can point out public prosecutor's office. Since recognition of general aspects of crime and social rights on public prosecution, an entity as "collective attorney" or "prosecutor" called "public prosecutor's office" was established to conduct the task of public prosecution on behalf of the government and society. The participation of NGOs in criminal process and accepting the right of complaining and prosecuting harm crimes for public interests in the laws of some countries was another manifestation of public interest in criminal justice entities.

\subsubsection{Public Prosecutor's Office}

Public prosecutor's office is a French entity. The most important factor is the tendency of judicial systems to establish Public prosecutor's office and the philosophy of its establishment is to pass human society from private to public administration of justice and consider a social aspect for crimes (Zyayi, 2011: 14). By changing French criminal procedure system to mixed system, for the first time in French criminal procedure law in 1808, Public prosecutor's office was tasked to protect public interests by exclusive rights of crime prosecution on behalf of the government (Ashury, 2008, vol. 1: 48).

The French term used to refer to Public prosecutor's office directly points out public interest protection; in France, Belgium, Luxemburg and Monaco, Ministère public is used and translated as public Ministry. Latin term Ministrare means to serve. In the Netherlands, Openbaar Ministerie and in Spain and Andorra, the term Ministerio Fiscal, in Portugal, the term Ministerio Público and in Romania, the term Ministerul Public are used 
which mean "public affair running" (Banchuk \& Taylor, 2013).

In Iranian laws, by adopting the law on legal entities and religious courts and peaceful verdicts in 1911 and extracting French criminal law (1808), "public claim office" was established and then changed to "Public prosecutor's office" in 1938. According to article 107 of the same law, "crime responsibility has two aspects: personal identity and public identity. Personal identity is when the loss of crime is fault and is allotted to a person while in public one, it is when the loss of crime belongs to public rights. Therefore, public claim office is established to protect public rights." Article 108 reads: "public claims include a board of judiciary officials and heads participate in legal cases and conduct their tasks on protecting public rights and monitoring crime execution." As seen, article 107 determines "public rights" against "certain person's rights" and defines crime private identity as violating the rights of certain persons and crime public identity as violating public rights. In this law, public right is defined as the right of society concerning public discipline and security of citizens (Dadyar, 2011: 13) to whom prosecutor is responsible to protect them.

The right of prosecution by public prosecutor's office on behalf of the society in order to protect public interests is manifested under one of the principles of criminal procedure namely principle of officiality. It means that criminal prosecution and starting criminal process is the exclusive right of the government and prosecutor acts upon this right on behalf of the government. On this basis, private prosecution is meaningless and citizens have no right for criminal prosecution and starting criminal process. They have only the right to notify prosecutor on crime commission. The governance of officiality principle and the right of exclusive prosecution by public prosecutor's office is so important in French criminal laws by which victim was neglected in criminal process and could only ask prosecutor for compensation as a private plaintiff. This situation was kept on till 1960 when criminal branch accepted that initial complaint along with plaintiff's petition can start public claim if no action is taken by public prosecutor's office (Gessen, 2006: $342-343$ ).

For public claims, public prosecutor's offices use one of two systems dominating criminal prosecution or their combination. They include principle of mandatory/ principle of legality and principle of opportunity/ Expediency principle for criminal prosecution. The principle of mandatory means the prosecution of any crime is necessary if evidences exist upon the notification of prosecution official (Sheydayan, 2009: 13). The principle of opportunity means authority in prosecution decision or lack of criminal prosecution (ibid: 24). While assigning prosecution autonomy to prosecution official, this principle has limited it to public interest (ibid: 301 ).

Since the basis of establishment and operation of public prosecutor's office and public prosecution official is to provide public interest, both principles attempt to realize this aim; one believes that public interest is prosecuting each explored crime and another one believes that public interest is either in leaving prosecution of some crime or in assigning prosecution by prosecutor's discretion. On the same basis, prosecutor is obliged to prosecution in the system and he should do his best on prosecution upon confirming the adequacy of assigned evidences to the accused while in the principle of opportunity, prosecutor should confirm public interest in addition to confirming the adequacy of evidences.

In other words, in principle of mandatory, the only authority for recognizing public expedience is lawmaker since by Montesquieu's insights, if the power of lawmaking and execution are not separated; radical liberties of people are damaged. Judge's dignity is not in making laws and he should be the tongue of the law. In other words, judge should be limited to legal items. In criminal affairs, such limitation and necessity is reflected more and judicial official's authorities should be reflected in criminal procedure in a clear and detailed manner (Kushki, 2010: 328). In contrary, the principle of opportunity assigns the autonomy of expedience in some fields to prosecution official and it deviates from Montesquieu's power separation rule by such justification that all expediencies are not already predictable by lawmaking authority.

By article 79 of the law on the principles of judiciary entities, "public claimants are obliged to investigate and prosecute those actions which cause offences or injury or crime", Iranian laws have explicitly accepted principle of mandation which is continued nowadays. There have been always attempts for limited and controlled propensities toward principle of opportunity. Article 40 of annexed criminal procedure law (1973) as well as article 22 of Administration of Justice Laws reforms (1978) and articles 80 - 82 of the new Criminal Procedure Law are examples of such propensity to principle of expediency. Initiatives like case archive in grades 7 and 8 of discretionary crimes and protective prosecution postponing and referring to mediation in grades $6-8$ of discretionary crimes are accepted.

\subsubsection{Non-governmental Organizations (NGOs)}

Non-governmental organizations (NGOs) play a vital role in today's social life. Their main traits include: (1) independence for government's direct control; (2) lack of the status of a political party; (3) a non-profit structure; 
and (4) non-criminality of the target such as nonviolence (Wilkowska-Landowska, 2006, p 99).

Among the most important roles of NGOs, one can point out their role playing in shaping, executing and monitoring of regulations (Ramezani, 208: 91), training, notification and mobilizing public opinions and pursuing civil, criminal and administrative claims related to public interest. As pressure groups, these organizations play a vital role in converting some public interest implications to law. Many international treaties have considered as necessary the litigation rights of NGOs in different areas especially environmental rights. Many countries have recognized this right for NGOs in different fields related to public interests. Such role supplements other roles in organization and litigation rights and is in fact conducted as a guarantee of executing follow-ups, supervisions, trainings, notifications and mobilizing public opinions through judicial and administrative authorities. If neglected by prosecution officials, it can disappoint sympathetic NGOs.

Laws in France, Portugal and Italy have paved the way for their registered NGOS to intervene in national criminal procedure and compensation claim for environmental damages. They can notify public prosecutor of any action which forms an environmental crime. Upon starting criminal researches, NGOs can be a private prosecutor (who helps public prosecutor or even can disagree with him when for instance prosecutor decides not to continue prosecution). Italian registered NGOs can contribute in criminal procedures on environment to ask for compensations on behalf of involved citizens or on special environmental interests pursued by NGOs (Sadeleer, Roller and Dross, 2002, p 19).

Research findings on environmental rights indicate that "the possibility of NGOs' participation in criminal procedure (as seen in France and Portugal) is an important tool to execute environmental rights better. For instance, water and wild life regulation in France are executed better since NGOs can pursue compensations for criminal courts (de Sadeleer, Roller and Dross, 2002, p 14).

In Iranian laws, article 16 of executive recipe of establishing and operating NGOs (2005) and then article 66 of criminal procedure law (2013) can be seen as the implications of granting NGOs' contribution rights in prosecuting crimes against public interest. Although conducted reforms (2005) which led into changing the term "in all procedure steps, NGOs can object providing evidences and verdicts by judicial officials" to "they can participate in all procedure steps", it has caused such contribution unfruitful in practice. Article 14 of the law on supporting recommenders to do well and enjoining not (2015) has also developed the verdicts by article 66 .

\subsection{Criminal Process}

Criminal process means different steps of criminal procedure from crime exploration to execution and punishment (Ghapanchi and Danshnary, 2012: 169 - 170). Criminal law connoisseurs have provided different models to clarify this process and its dominating values. One of the most famous modeling is conducted by Herbert Packer as the criminal laws instructor in Stanford University. He identified two main models on criminal process in USA as "crime control model" and "due process model" (Packer, 1968: 6) which can be extended and adapted to other criminal justice systems.

These two models can be explained by public interest and its most important challenge namely individual rights addressed in next section. In the relationship between public interest and individual rights, crime control model gives priority to public interest and due process model gives priority to individual rights especially the accused's right of due process.

On this basis, in crime control model, the ultimate aim of criminal justice system is to provide sustainable security in the society albeit with the expense of punishing innocent people. Its raise deter is to protect social system (Qapanch and Daneshnary, 2012: 170 - 171). The effort by criminal justice system is remarkably to arrest the accused people immediately and convicting and punishing them. As a result, the rights of the accused are highly neglected. The main strategy of this model is to provide security through intensive criminal action and violating due process rules.

Plead guilty statistic or delinquency assumption is seen as the key of crime control model (www.cliffsnotes.com/which-model-crime-control-or-due-process). According to plead guilty statistic, the accused should prove his/her innocence. Likewise, resorting to torture and violating the right of silence, accelerating criminal trials (Qapanchi and Daneshnary, 2012: 169), plea bargaining by the attendance of jury trials in order to improve the velocity (www.slideshare.net/sevans-idaho/packers-models-of-criminal-justice), wide usage of pretrial detention which encourages the accused to confess plead guilty and developing DNA databases for samples taken from all born babies in the country (www.slideshare.net/sevans-idaho/packers-models-of-criminal-justice) are other outcomes of such model.

The second model is due process model. It attempts to create this imagination that sometimes the accused's 
rights are preferred to the rights of the society. This model attempts to establish justice in criminal process by due process strategy and respecting human dignity of the accused (Qapanchi and Daneshnary, 2012: 169).

In this model, the main performance of criminal courts is impartial judgment in conflicts between government and citizens. Although providing security is important in due process, this model does not emphasize on security establishment through any way since the main axis of law - oriented law is to protect the rights of people and respecting citizens' liberties. Based on this model, criminal justice system has no superiority to the accused; rather, there is judicial equality on relations between both parties (Qapanchi and Daneshnary, 2012: 172 - 173).

Due process model is based on doctrine of legal guilt and presumption of innocence. In this model, the assumption is on the principle of people's liberty and their detention is an exceptional issue. Pretrial detention should be used a minimum in all cases and people should have the right of freedom when they are not recognized as guilty otherwise they are seen as a serious threat against society (www.slideshare.net/sevans-idaho/packers-models-of-criminal-justice) which needs strong evidences and one cannot arrest individuals only by possible evidences. The principle of temporary detention is recognized in most developed countries (Omrani, 2009: 33) and is based on the same perception. The rule of considering non valid the collected evidences out of legal norms (Qapanchi and Daneshnary, 2012: 172 - 173) and limiting DNA databases to only taken samples from registered suspects or fingerprint are other effects of this model domination.

It may initially seem that crime control model is the main manifestation of public interest in criminal process and due process model has no relation to this concept. However, it seems that crime control model is more looking for realizing a public and surface and nondemocratic perception of public interest which will finally damage public interest. In modern perception, one cannot sacrifice individual rights which ensure the individuality of society's members for public interest. It easily happens by negating some fundamental rights and even citizens' absolute rights like innocence assumption and torture protection rights. Likewise, based on a multifactor definition on public interest, one can claim that an implication of agreed public interest is to respect individual rights and liberties. Therefore, based on the second approach on due process and based on comprehensive definition, one can claim that due process model provides public interest more fully and sustainably

\section{Public Interest Challenges}

As mentioned, on the one hand, procedural criminal laws are formed by public interest and providing public security and social rights and regulations, processes and entities are created to provide the same goal. On the other hand, individual rights are supported by criminal procedure rules. As a bumper against claims, accusations and initiatives by prosecution officials as the representative of society's public interest, these rights are assigned to under investigation citizen (the accused). The status of public interest and individual rights are so that the aim of criminal procedure is to achieve a balance point between them.

Public interest or common goodness has a long history as same as collective life and forming human communities. By forming individualism and tights in modern age, it is impossible today to define public interest without considering individual and his/her rights and interests and even individual liberties and rights are seen as an implication of public interest. Since full adaptation of individual interests with public ones is impossible, the most important limiting factor of individual rights is still public interest (Anthony, 2010: 2). In our age, individual rights status is so high that in discussion, individual rights are always grated integrity and public interest albeit in its new concept, it is raised as an exception.

In international and regional human right documents, the possibility to limit individual rights by public interest and its important implications such as public security and discipline, public health and public welfare are admired. Internal laws of many liberal countries have recognized individual rights limitation by public interest. Iranian Constitution Law has predicted rights exertion limitation in its article 40: "no one can exert his/her rights by damaging others or violating public interests." On this basis, one can only limit actions that violate public interests or damage other people.

One can decisively say that criminal procedure regulations are one of the most explicit areas of relationship between public interest and individual rights and liberties. It has become more explicit by expanding terroristic attacks, expanding organized crimes and crimes like money laundry which seriously jeopardize public discipline, security and welfare so that Legislature ratifies a legal democratic liberal system lime USA Patriot Act in the excuse of preventing terroristic crimes by providing a broad definition on terrorism by which it granted paramount authorities to FBI and judicial officials to limit fundamental rights and liberties (Gorji, 2004: 19 20). 
Now, one should observe to which category of rights in criminal procedure, public interest will be interfered? According to a categorization, rights are divided into procedural and substantive ones. Substantive rights are the same rights mentioned in legal systems which have value for holders per se and are supported legally. In contrary, procedural rights are used to support and realize substantive rights. In other words, procedural rights are valuable since they are utilized to realize substantive rights (Farahbakhsh, 2006: 117 -118).

The role of procedural rights in operating substantive rights is so that one can claim without them; substantive rights will be remained as written in law without the power of emergence. to the same reason, procedural rights have extraordinarily developed so that one can say that one of the differences by modern and previous rights is the narrowness of procedural rights in recent century and its fatness in modern system since human has today found that the best rules with substantive rights will be remained abandoned when no proper executive guideline is predicted for them (ibid).

According to some authors, one can divide procedural rights on criminal procedure into two major rights and consider other rights as their branches: "the right of innocence assumption" and "due process right" . A major part of the accused's rights and its guarantees like the silence right of the accused are emanated from innocence assumption. Such issues as court impartiality, court independence, pretrial guarantees (police investigations) and innocence assumption are the implications of using due process (ibid: 130), these are two radical rights recognized in constitutions of most nations.

Although defensive rights of the accused are procedural rights, individual rights supported by criminal procedure are not limited to procedural rights and many substantive rights are also supported. Substantive rights are supported by criminal procedure and include such rights as free transportation, torture protection and privacy right as the fundamental rights recognized by constitution laws of countries. These rights are recognized for the accused by procedural rights through criminal provisional remedies especially detention remedy, how to take the accused's confession, how to inspect homes and so on supported by lawmaker.

Overall, individual rights are supported by criminal procedure either procedural or substantive and can interfere with others' individual rights and public interest. Interference of the accused's rights and victim's rights are like interference in criminal procedure out of our discussion. In interference of public and individual expediency, two moods can be imagined. Conflicted right is a fundamental right (or second degree right). It seems that individual rights supported by criminal procedure either substantive or procedural root in two mentioned fundamental rights. The results of separating fundamental and non-fundamental rights are determined in the theory by Durkheim as a non-utilitarian liberalist thinker. According to him, fundamental rights are not limited by public interest.

\subsection{Challenge by Innocence Assumption Right}

From innocence assumption, these titles are interpreted "joint legal heritage of all advanced nations" (Ashury, 1993: 39), "mother of principles" (Shams, 2002: 72), "legal rights fundamental cross - principle" (Qapanch and Danshnary, 2012: 175). This principle addresses the necessity of plaintiff or public prosecutor to prove accusation and to give evidences, the necessity to describe laws and to resort to doubt interpretation principle on the benefit of the accused, prohibition of resorting to hidden and illegal methods to achieve evidences such as torture, cancelling judgment in the case of resorting to such methods and so on in trial protocols and the rights like accusation explaining in the first hours of accusation or detention, silence right, the right of enjoying attorney in the first hours of judgment in all courts (Shamlu, 2004: 278 - 279).

The cases of derogating clearance principle is more or less existing in the laws of different countries even those ones that have considered it as a dominating principle on criminal laws. They are often raised where crime commission causes serious damages against society or poses a serious threat and it is impossible to prove the crime by public prosecutor and prosecution officials due to certain complexities of the crime (Shams, 2002: 75 76). Therefore, exceptions of clearance principle are accepted by "public interests" (Khazani, 1993: 131).

In fact, guilty assumption means to violate citizens' fundamental rights by justifying public interest. The most important preference of guilty is based on innocence assumption which include crimes against internal and external security, drug trafficking, terrorism, war crimes and crimes on suspicious wealth like money laundry. Iranian lawmaker has fully refused guilty on drug trafficking and has predicted the seizure of all assets (articles 4 and 5 and article 8(4,5 and 6) of the law on illicit drug campaign reforms ratified by Expediency Council, 1997). In the laws of many European countries, guilty on suspicious assets are preferred to clearance principle (Shams: $80-81)$. The preference of public interest and, as a result, guilty principle has impacts on total criminal procedure. The main impacts include inversion of the evidence determination load, self-criminalization, accepting oral documents, obtaining evidences by illegal techniques like torture, neglecting the accused's silence right, limited accessibility to attorney, so on. 
It seems that Iranian criminal procedure has supported citizens' fundamental rights further. For instance, Iranian lawmaker has not accepted self - criminalization and does not allow judges to conclude it by inspirational questions. Article 60 of criminal procedure law reads: "in inquiry, it is forbidden to enforce the accused, to use bad words, to raise inspirational questions or questions out of the sphere and the accused's statements in answering such questions are not valid." The same verdict can be seen in article 195: "inspirational question by enforcement is forbidden." Likewise, the right of accessibility to attorney is explicitly accepted in article 48 and the accused' silence right in article 197 and in article 38 of Iranian Constitution, torture is totally prohibited. Only some limited exceptions are mentioned in article 48.

\subsection{Due Process Challenge}

According to article 14(1) of political and civil rights covenant, anyone has the right to be judges against his accusations or commitments in a fair trial/fair hearing. It is also mentioned in article 6(1) of European Convention to support human rights and radical liberties (Omidi, 2003: 121). According to European human rights commission, equality of arms is an inner element of a fair trial (Omidi, 2013: 121). Sometimes, Americans say that criminal procedure should be a fair fight between government and the accused. Others interpret criminal procedure as equal arms (Siegel and Zalman: 116). Equal arms mean that each party should provide its claims under conditions which do not put it in situations remarkably worse than another party (Saghian, 2006: 80). Respecting equal arms is not always adapted to public interest. Particularly in initial investigations, it is sometimes necessary that prosecution and investigation officials have more freedom than attorney and the accused. It is acceptable when it does not damage this right and is adapted to equal arms concept. In French laws, appeal deadline is 2 months for prosecutor while it is 10 days for other parties of the claim. However, French Supreme Court believes that additional time for prosecutor is not in contradiction with equal arms principle since other parties have the right of appeal even though it is less than determined time for public prosecutor. Some French jurists have confirmed it since they believe that public prosecutor's office defends the interests of total society while accused only defends his/her own interests (Saghian: $92-93$ ). Sometimes, such expediency orientation would violate this right by which trial is not seen fair. For instance, in criminal investigation of France (1808) and the law on reforming criminal judgments in Iran (1913), the right of using attorney in preliminary investigations is not forecasted for parties which are in contrary to equal arms. It was recognized initially by France (1897) and then by Iran (1956) (Saghian, 94 - 95).

In new Iranian new procedure law, respecting this right is remarkably improved. Clarifying the right of meeting with attorney since the beginning of monitoring the accused (article 48), the right of having attorney in preliminary investigations (article 190) and interrogator's disciplinary punishment due to depriving such right or lack of explaining it to the accused (article 190), the necessity to select court appointed attorney for the accused in preliminary investigations concerning the offences that their punishment is depriving life or life sentence, the right of studying and access to the files by the accused and his/her attorney except than certain cases or inaccessibility award which can be objected (article 191) are all signs of lawmaker's efforts to establish balance between the accused and public officials.

Confidentiality of preliminary investigations is interpreted to respect innocence assumption since despite of considering preliminary investigations as confidential in article 191 and predicting punishment on disclosing secrets for those ones who participate in preliminary investigations are not seen by lawmaker in contradictory to accessibility to the contents of the cases for defense by the accused and recognized by article 191. In the same law, one can observe implications on public interest preference to due process or equal arms. For instance, according to article 48 of the same law, in crimes against internal or external security as well as organized crimes that their punishment is mentioned in article 302, in preliminary investigations, parties select attorney from registered attorneys confirmed by Judiciary Head. The names of them are announced by Judiciary Head. Since the issue has security aspects, all attorneys are not seen as competent and the accused cannot select his/her trusted attorney freely. The limitation by article 19 namely the cases that interrogator negates study or accessibility to all or parts of documents to explore the reality or crimes against internal or external security, it can prohibit the accessibility of the accused and his/her attorney to the case which would scatter equal arms in the benefit of public authorities. However, predicting inaccessibility remedy in this article can reduce excessive expansion of this exception and can protect citizens' rights against public officials' decisions.

\subsection{The Right to Freedom of Action Challenge}

The right to freedom of action is a substantive fundamental right clarified in constitutions of many countries (Gorji, 2004: 10). Under investigation accused has such right and using this right needs no justification. To the same reason, the accused should enjoy full liberty during claim and investigation. Issuing provisional and 
temporary detention remedies in preliminary investigation has no background justification and it is simply justifiable by practical necessities which need a strong argument of expediency of provisional remedy (Farahbakhsh, 2006: $127-128$ ). Temporary detention is the heaviest provisional remedy issued for important offences. Consistency of this remedy and imprisonment has caused its short term on the one hand which is lower than the imprisonment of the committed crime by the offender and, on the other hand, if the accused is convicted, time of his/her detention will be mitigate from his/her imprisonment determined by the court (Allipour, 2009: 17 $-18)$.

Here, the challenge is the necessity of obtaining intensive provision like temporary detention which requires public interest for important crimes on the one hand and the right of the accused for freedom of action until conviction on the other hand. To the same reason, most advanced countries attempt to limit temporary detention scope by establishing relevant rules and use it only in necessary conditions. The main principles which govern temporary detention include: (1) disagreements on decision for temporary detention; (2) separating inspection and issuing entities for temporary detention remedy; (3) the necessity to mention evidences and arguments for remedy; (4) objection ability; (5) remedy length; (6) remedy threshold; (7) the possibility of asking for losses from unjustified temporary detention for arrested person and (8) subordinate principle of issuing temporary detention remedy. The last principle means that temporary detention is an exception on citizens' liberty principle. This principle is defined country-by-country differently. For instance, in Wales and UK, the principle is the accused's pretrial liberty and temporary detention is always an exception for this principle. In France, Germany, Denmark, Spain and Italy, temporary detention is only applicable which other judiciary initiatives cannot be executed (Omrani, 2009: 34).

In the past, article 35 of criminal procedure law (1999) and disperse regulations in substantive laws like the law on intensifying the punishment of embezzlement, bribery and fraud perpetrators (1990) have predicted necessary temporary detention remedy issuance while by an explicit procedure change toward subordinate principle, article 237 of criminal procedure law (2013) emphasized on the exceptionality of this remedy in article 237 and article 238. According to this article, issuing temporary detention remedy is not allowed otherwise on below crime for which there is sufficient arguments and evidences on accusation of the charged person. In this article, lawmaker has gone beyond and in article 237, the cases of necessary temporary detention are cancelled except that special laws on armed forces' crimes. In article 242, in addition to periodical investigations (one or two months), temporary detention remedies are determined to mitigate or cancel the remedy. "The accused's detention should not exceed the minimum determined punishment in the law for that crime and in any case, in the crimes which require depriving from life, temporary detention should not be more than two years and more than one year in other crimes." The paragraph of this article has extended the maximum detention period to all remedies led into temporary detention. Likewise, article 255 has recognized the right of asking for the compensation for detention period from government for those people who are arrested during preliminary investigations and adjudication and then their clearance or prosecution forbiddance remedy is issued by judicial authorities.

Therefore, one can say that to resolve such interference, Iranian lawmaker has taken a high step toward protecting citizens' fundamental liberty right and public interest in new criminal procedure law rather than limiting it. However, there are still concerns in this regard. For instance, assigning the issuance of temporary remedy to interrogator and lack of predicting a criminal procedure with defense right for issuing such important remedy can jeopardize citizens' liberties albeit such concerns are remarkably mitigated.

\subsection{The Right of Privacy Challenge}

The right of privacy can be seen as one of the most fundamental human rights which have a close and direct relationship with human personality (Rahmdel, 2005: 120). The right of privacy is described as a field of private life determined by laws and traditions and has no relation to public so that interferences by others may injure a person's feelings or his/her humiliation in front of others (Rahmdel, 2005: 120). In the declaration by European officials participating in International Jurists Commission in Stockholm (1976), one can read that the right of hearing telephones, seeing users' registered information by Internet Service Providers such as sharing the information of the size of provided services as well as the resources of paying Internet service costs and Internet protocol addresses should be conducted with the minimum intervention in the life of other people (Aghababaei, 2010: $4-5)$.

In contrary, public interest requires that lawmaker grants widespread autonomy to government on recording and controlling letters for preventing terroristic actions, identifying the terrorists and scattering the link between them and their supporters. US Patriot Law has permitted broad eavesdropping of wireless, oral and electronic conversations (Allipour: 13). To prevent financial aids to terrorists and multilateral supervision on monetary and 
banking transactions and money laundry, lawmaker has not only allowed banking secrecy but also has obliged banks to identify their customers and to inform on transferring suspicious sums (Aghababei, 10). Controlling the letters, messages, telephones, and information is the most important part of increasing the autonomies of police and officers of administration of justice. It is accepted more than other guidelines since it is not a confrontation between police and citizens.

In Iranian criminal law, there are many cases of criminal procedure laws on ensuring citizens' privacy against inquisition and inspections by investigative officials. In addition to article 22 of the Constitution, articles 78, 79, 96, 97, 98, 99 and 100 of criminal procedure law (1999) and articles 580 and 694 of discretionary laws are adopted to protect the right of privacy. In criminal procedure (1999), consideration, inquisition and inspection of postal, communicative, audio and video correspondences are allowed only when necessary for crime exploration under the order of judicial official. According to article 104, telephone controls were dispersed by two ambiguous national security and persons rights terms. Accordingly, phone control is forbidden except in cases related to national security or the rights of individuals by judge's order.

In criminal procedure (2013), while article 4 emphasizes on respecting citizen's privacy as a general rule over criminal procedure, articles 57, 87, 150,151, 152 and 154 of the same law introduce implications of public interest and individual rights (the right of privacy) interference and attempt to prefer public interest to individual rights in a certain framework. For instance, article 56 reads: "judicial officers are obliged to act based on issued permission and refuse inspecting irrelevant people and locations." However, the next article, has excluded inspecting evidences and tools which threat public security and convenience.

In other articles, lawmaker has prescribed seizing suspicious packs by post officers and immediate notification to public prosecutor in the case of a strong possibility that such packs contain illicit drugs, toxic materials, dangerous microbes materials and/or explosives, warm weapon and security items (article 87); controlling telecommunications related to internal and external security and/or for exploring crimes under article 302(a)(b)(c)(d) (article 150); controlling accounting banks (151); inspecting postal correspondence on the accused people when there is strong suspicious on crime exploration and achieving crime commission evidences or the accused identification (152); and the necessity to disclose effective documents in crime exploration assigned to attorney or another person (154). All these implications are due to public interest preference to privacy of the people that allow investigative officials to enter citizens' privacy for providing interests while one can see the efforts of respecting the right of privacy and exceptionality of public interest preference to individual rights throughout new criminal procedure law.

\section{Conclusion}

To provide public interest, laws are devised and adopted. All public services provided by administration to citizens are looking for proving a public interest implication. Justice execution and social order and security are a service provided by crime prosecution, judgments and executing the verdicts by criminal justice system. It is as same as other public services which look for public interest. Criminal procedure law is formed as a method of criminal justice execution by public interest orientation.

It seems that five factors are involved in elucidating public interest concepts: common interests, process respect and legal protocols, attracting the opinions of majority, attracting highest profitability for most people and adaptability with society's common values by which one can achieve a relatively comprehensive and thorough conception on public interest. On this basis, although public interest is independent from private interests, it is not neglected in shaping the concept of individual rights and even plays a role.

Public interest is manifested in criminal procedure, criminal process and governing entities and regulations. Public prosecutor's office is established to purvey public interest and governing principles on criminal prosecution claim public interest purvey. Criminal process models are different based on respects to public interest and each one claim more purveying of public interest. Criminal procedure regulations including competencies and criminal provisional remedies supervise public interest purvey.

Another trait of modern societies is to accept a series of ethical principles as the rights to foster human individually. Day-by-day, individualism is getting more profound in all societies including Iran and such individuality fostering would strengthen right - oriented view. Citizens no longer seem themselves obliged to lawmakers' orders and they consider rights to which lawmaker needs justification for their limitation or deprivation.

As clarified in international documents and internal laws, public interest is seen as the main ethical justification for such limitation. In past, such limitation meant sacrificing individual rights against public interest while today 
one cannot represent a right definition of public interest without considering individual rights. One can claim that respecting citizens' individual rights purvey society's expediency.

On this basis, new Iranian criminal procedure law has become right - oriented more than ever. Using individual rights and limiting public interest tools were among the important aspects of Iranian new criminal procedure. Exceptionality of issuing temporary detention and eliminating necessary temporary detention in nonmilitary crimes are clear evidences on such claim. Although main orientation by Iranian lawmaker is toward this, inquisitorial procedure signs are still seen.

\section{References}

Aalipour, H. (2009). National security and the accused's Rights; comparative study of procedure law on terroristic actions. Strategic Studies Journal, 43, 5-44.

Aghababei, H. (2010). Security scope in criminal laws (1st ed.). Tehran: Islamic Culture and Thought Research Center Publications.

Anthony, G. (2011). The Public Interest and Prosecutions. Retrieved from http://amnesties-prosecution-public-interest.co.uk/project-outputs/public-interest-prosecutions

Ashury, M. (1993). The presumption of innocence and its effects on criminal affairs. Political Science and Laws School, 29, 39-72.

Ashury, M. (2008). criminal procedure law (vol. 1, 13th ed.). Tehran: SAMT Publications.

Banchuk, A., \& Taylor, G. (2013). Prosecution vs. Prokuratura: the European experience concerning the title of prosecuting services. Retrieved from www.en.pravo.org.ua/index.php/149-criminal-justice/521-prosecution-vs-prokuratura-the-european-experie nce-concerning-the-title-of-prosecuting-services

Dadyr, H. (2011). The Role of Public Prosecutor in protecting public rights and its legal and executive challenges. Criminal Laws and Criminology doctoral dissertation, University of Tehran, Farabi collage.

Denhardt, J. V., \& Denhardt, R. B. (2010). The New Public Service (Expanded Edition).

Diggs, B. J. (1973). The common good as reason for political action. Ethics, 83(4), 283-293. http://dx.doi.org/10.1086/291887

Farahbakhsh, M. (2006). The concept and basics of the accused's defensive rights. The Judiciary Law Journal, 56-57, 111-135.

Gasen, R. (2006). Considerations on the aim of criminal procedure. translated by Shahram Ebrahimi. The Judiciary Law Journal, 59, 333-348.

Gorji, A. A. (2004). Basics and concept of fundamental rights. Constitutional Law, 2, 7-26.

Hart, H. L. A. (2009). Law, Liberty and Morality (1st ed.). translated by Mohammad Rasekh. Tehran: Tarh-e-No Publications.

Katouzian, A. N. (2009). Philosophy of Law: Volume I Essence and Defintion of Law (5th ed.). Tehran: Enteshar Company Publications.

Khaleghi, A. (2010). Criminal Procedure (6th ed.). Tehran: Shahr-e-Danesh Publications.

Khalil, F. (2003). The Concept of Public Interest in the Western Political Theory. Alnahda, 17, 3-40.

Khazani, M. (1993). The Presumption of Innocence and Reasoning in Criminal Action. law research magazine, 13-14, 125-144.

Kushki, G. H. (2010). Alternatives of Public Prosecution in Iranian and French Criminal Procedure Systems. law research magazine, 29, 327-350.

Mirmoosavi, S. A. (2005). Public Interest and Religious government. Culture and Thought, 13, 35-67.

Moeini Alamdar, J. (1999). Paradoxs of the Theory of Public Interest. Philosophy letter, 8, 194-211.

Omidi, J. (2003). Criminal Procedure and human rights. Parliament and Research, 38, 113-145.

Omrani, S. (2009). Temporary Detention and Citizenship Rights in Europe. Simorgh, 3, 33-39.

Omrani, S., \& Habib zadeh, M. J. (2013). Structural Analysis of The Relationship Between Criminal Laws and Political aknowledge. Islamic State Legal Studies, 3, 33-70. 
Packer, H. L. (1964). Two Models of The Criminal Process. University of Pennsylvania Law Review, 113(1), 1-68. http://dx.doi.org/10.2307/3310562

Pal, L. A., \& Maxwell, J. (2004). Assessing the Public Interest in the 21st Century: A Framework. Canadian Policy Research Networks Inc. Retrieved from: http://www.researchgate.net/publication/251889900_Assessing_the_Public_Interest_in_the_21st_Century_ A_Framework

Qapanchi, H., \& Danesh nary, H. R. (2012). Two Models of Criminal Process: Crime Control and Due Process. The Criminal Law Handbook, 4, 167-184.

Rahmdel, M. (2005). Human Right To Privacy. Law And Political science, 70, 119-145.

Ramezani, M. H. (2008). A contemplation on the role And status of NGOs in environmental criminal proceedings. Nameh-ye Mofid, 67, 91-110.

Rasekh, M., \& Bayat, M. (2013). Theory of public interest. In M. Rasekh (Ed.), Right and Expediency 2 (pp 555-575). Tehran: Tarh-e-No Publications.

Saaghian, M. M. (2006). The principle of equality of arms in criminal process (by relying upon the France and Iran Law). The Judiciary Law Journal, 56 \& 57, 79-109.

Sadeleer, N. D., Roller, G., \& Dross, M. (2002). Access to justice in environmental matters. Final Report. ENV.A.3/ETU/2002/0030.

Shamlu, B. (2004). Criminal presumption of innocence in new procedure systems. In Articles Collections of commemorate the $d r$. Ashuri (1st ed.). Tehran: SAMT Publications. 262-283.

Shams Naateri, M. I. (2002). the presumption of innocence and the cases of its derogation in criminal laws. Qom Higher Education Center Publications, 14, 65-88.

Sheydaian, M. (2009). Analysis of Opportunity Principle and its status in Iranian and Islamic criminal laws. doctoral dissertation, University of Tehran, Qom Pardis.

Wilkowska-Landowska, A. (2006). Friends of the court: the role of human rights non-governmental organisations in the litigation proceedings. Human Rights Law Commentary, 2, 99-119.

www.cliffsnotes.com/which-model-crime-control-or-due-process

www.slideshare.net/sevans-idaho/packers-models-of-criminal-justice

Zalman, M., \& Siegel, L. (1999). Criminal procedure as human rights, translated by Jalail Omidi. Political Science and Laws School, 44, 7-24.

\section{Copyrights}

Copyright for this article is retained by the author(s), with first publication rights granted to the journal.

This is an open-access article distributed under the terms and conditions of the Creative Commons Attribution license (http://creativecommons.org/licenses/by/3.0/). 